\title{
Pengaruh Level Pemberian Tepung Kunyit (Curcuma domestica Val) dalam Ransum terhadap Karkas Itik Lokal
}

\section{The Effect of Various Amount of Turmeric Powder (Curcuma domestica Val) In Ration Toward the Carcass of Local (Pitalah - West Sumatra) Duck}

\author{
T.D. Nova, Sabrina dan Trianawati \\ Fakultas Peternakan, Universsias Andalas \\ Email: tertiaunand@ymail.com \\ (Diterima: 11 Mei 2015; Disetujui: 16 Juli 2015)
}

\begin{abstract}
ABSTRAK
Penelitian ini bertujuan untuk mengetahui pengaruh pemberian tepung kunyit dalam ransum terhadap karkas itik lokal. Penelitian ini menggunakan 80 ekor DOD itik Pitalah jantan yang ditempatkan pada 20 unit kandang boks. Metode penelitian secara eksperimen menggunakan Rancangan Acak Kelompok (RAK) dengan 4 perlakuan dan 5 kelompok bobot badan sebagai ulangan. Perlakuan yang diberikan dalam penelitian ini adalah A (tanpa pemberian tepung kunyit/kontrol), B (pemberian tepung kunyit $0,2 \%$ ), $\mathrm{C}$ (pemberian tepung kunyit $0,4 \%$ ) dan $\mathrm{D}$ (pemberian tepung kunyit $0,6 \%$ ). Peubah yang diamati meliputi bobot karkas, persentase bagian bagian karkas (dada dan paha) dan persentase karkas. Hasil penelitian menunjukkan pemberian tepung kunyit dalam ransum berpengaruh tidak nyata $(\mathrm{P}>0,05)$ terhadap bobot karkas, persentase bagian - bagian karkas (dada dan paha) dan persentase karkas. Berdasarkan hasil penelitian dapat disimpulkan bahwa pemberian tepung kunyit sampai dengan level $0,6 \%$ dalam ransum tidak mempengaruhi bobot karkas, persentase bagian - bagian karkas (dada dan paha) dan persentase karkas.
\end{abstract}

Kata Kunci: Level tepung kunyit, itik local, karkas

\section{ABSTRACT}

This study was aimed at determining the effect of turmeric powder in the ration of local duck carcass. This study used 80 heads of male and a day old duck (DOD) of Pitalah duck with 20 units of cage. The experiment used a randomized block design (RBD) with 4 treatments and 5 groups as replication on the weight basis. The treatments consisted of four types; A (without turmeric powder I as a control), B (given turmeric powder at 0.2\%), $C$ (given turmeric powder at $0.4 \%$ ) and $D$ (given turmeric powder at 0.6\%). The observed parameters were carcass weight, carcass percentage and the percentage of breast and thigh. The results showed that turmeric powder in the duck ration affected the carcass weight, the percentage of breast and thigh and carcass percentage at a not significant level $(P>0.05)$. Therefore, the turmeric powder at the level of $0.6 \%$ in duck diet did not affect their carcass weight, the percentage of breast and thigh and carcass percentage.

Keyword: Level turmeric powder, local duck, carcass

\section{PENDAHULUAN}

Kebutuhan protein yang berasal dari ternak semakin meningkat dengan bertambahnya penduduk serta kesejahteraan masyarakat. Untuk memenuhi kebutuhan tersebut, diantaranya bisa didapatkan dari ternak unggas seperti ayam dan itik yang berkontribusi sebagai penghasil telur dan daging.

Itik merupakan salah satu jenis unggas air yang keberadaannya telah lama menyatu dengan kehidupan masyarakat Indonesia. Pemanfaatan itik sebagai sumber protein sangat potensial mengingat itik lebih resisten

Pengaruh Level Pemberian Tepung ... (Nova, et al.) 
terhadap penyakit dibanding ayam potong, memiliki daya adaptasi yang cukup baik dan itik memiliki efisiensi mengubah pakan yang berkualitas jelek menjadi daging maupun telur (Akhadiarto, 2002).

Daging itik mulai banyak diminati oleh konsumen karena memiliki rasa yang gurih berbeda dengan unggas pedaging lainnya. Hal ini dapat dilihat oleh terjadinya peningkatan terhadap produksi daging itik dari tahun ke tahun yaitu pada tahun 2011 produksi daging mencapai 28.184 ton, diikuti tahun 2012 naik menjadi 33.610 ton dan pada tahun 2013 mencapai 36.154 ton (Dirjen Peternakan, 2014).

Akan tetapi, daging itik memiliki kelemahan seperti rendahnya tingkat perdagingan dengan kandungan lemak yang tinggi jika dibandingkan dengan ayam pedaging. Kandungan lemak pada itik yaitu $8,2 \%$ per $100 \mathrm{~g}$, angka ini lebih tinggi jika dibandingkan dengan ayam pedaging yaitu $4,8 \%$ per $100 \mathrm{~g}$ (Srigandono, 1997), maka diperlukan suatu terobosan atau inovasi agar itik mampu menghasilkan kualitas karkas baik dengan daging yang lebih layak untuk diterima oleh konsumen.

Karkas yang baik dapat diperoleh dengan menambahkan bahan additive yang dapat memacu pertumbuhan. Biasanya bahan tambahan yang diberikan berbahan dasar antibiotik sintetik/kimia. Bahan ini ada yang bersifat kurang baik bagi manusia yang mengkonsumsinya. Hal ini disebabkan oleh timbulnya efek residu dalam karkas itik dan jika penggunaan antibiotik dilakukan secara terus menerus, maka akan mengakibatkan resistensi terhadap antibiotik bagi ternak. Adanya resistensi Salmonella sp terhadap antibiotik pada itik telah dilaporkan oleh Istiana (1997), terbukti bahwa dari 70 isolat Salmonella typhimurium ditemukan resisten terhadap ampisilin sebesar (30\%), neomisin $(12,8 \%)$, tetrasiklin $(11,4 \%)$, streptomisin $(8,6 \%)$, trimetropin $(7,1 \%)$ dan kloramfenikol $(5,7 \%)$. Data ini menunjukkan bahwa beberapa preparat antibiotik sudah kehilangan efektifitasnya dan cenderung menimbulkan resistensi mikroba yang semakin meluas. Jadi, untuk mengantisipasi hal tersebut diperlukanlah bahan yang bersifat alami yang ditambahkan ke dalam ransum itik.

Salah satu bahan alami yang dapat ditambahkan ke dalam ransum adalah kunyit (Curcuma domestica Val) dalam bentuk tepung, yang difungsikan sebagai feed additive bagi ternak itik. Hasil analisa laboratorium nutrisi ruminansia dan kimia makanan ternak fakultas peternakan Universitas Padjajaran (2002), bahwa tepung kunyit mengandung protein kasar $(12,23 \%)$, serat kasar $(10,85 \%)$, lemak $(1,67 \%)$, abu $(15,13 \%)$, kalsium $(0,13 \%)$, fosfor $(1,46 \%)$ dan energi metabolis $(3247,63 \mathrm{kkal} / \mathrm{g})$, juga mengandung atas minyak atsiri $(3,18 \%)$ dan zat warna kuning/kurkumin $(9,61 \%)$ (Hasil analisa Balai Penelitian Tanaman Obat dan Aromatik di dalam Sinurat et al., 2009). Kurkuminoid kunyit mengandung 3 komponen, yaitu kurkumin, desmetoksikurkumin, dan bisdesmetoksikurkumin (Rukmana, 1994).

Menurut Kusumawardhani (1988) dalam Pratikno (2010), pemberian kunyit dalam ransum dapat meningkatkan bobot badan, mengoptimalkan konversi pakan, serta menurunkan lemak. Hal ini didukung oleh penelitian Rahmat dan Kusnadi (2009), yang mencoba memberikan kunyit terhadap ayam broiler umur 2 minggu dengan level: (0\%); $(0,05 \%) ;(0,1 \%) ;(0,2 \%)$ dan $(0,4 \%)$ pada suhu panas dan dingin. Kunyit yang diberikan pada level $(0,2 \%)$ dapat meningkatkan pertambahan bobot badan pada suhu panas dan menunjukkan nilai konversi ransum paling efisien dibandingkan semua level. Pada suhu panas $(30-33)^{\circ} \mathrm{C}$ terjadi peningkatan pertambahan bobot badan dari $552 \mathrm{~g}$ pada kontrol menjadi $578 \mathrm{~g}$ dengan nilai konversi ransum $(1,98)$ yang nyata lebih rendah dibandingkan kontrol $(2,16)$. Ini dikarenakan pada suhu panas yang tinggi, kunyit yang memiliki senyawa aktif berupa kurkumin memiliki gugus hidroksil yang memudahkan kurkumin mendonorkan hidrogen dan elektrón kepada radikal bebas, sehingga radikal bebas menjadi stabil (Pietta, 2000). Hasil ini sejalan dengan penelitian Bintang dan Nataamijaya (2006) yang melaporkan bahwa pemberian 
kunyit $(0,04 \%)$ pada broiler umur 35 hari yang dikombinasikan dengan lempuyang sebanyak $(0,02 \%)$, nyata memperbaiki bobot karkas dari $1475 \mathrm{~g}$ (pada kontrol) menjadi $1749 \mathrm{~g}$.

Darwis, et al. (1991) menambahkan bahwa senyawa kurkuminoid dalam kunyit, mempunyai khasiat anti bakteri yang dapat meningkatkan proses pencernaan dengan membunuh bakteri yang merugikan serta merangsang dinding kantong empedu untuk mengeluarkan cairan empedu sehingga dapat memperlancar metabolisme lemak. Ditambahkan Purwanti (2008), mekanisme kurkumin dan minyak atsiri dapat meningkatkan nafsu makan ternak dengan mempercepat proses pengosongan isi lambung. Menurut Yuniarti (2011) kunyit dapat meningkatkan kerja organ pencernaan unggas, karena kunyit memiliki fungsi merangsang dinding kantong empedu mengeluarkan cairan empedu dan merangsang keluarnya getah pankreas yang mengandung enzim amilase, lipase dan protease yang berguna untuk meningkatkan pencernaan bahan pakan seperti karbohidrat, lemak dan protein.

\section{Rancangan Penelitian}

\section{METODE}

Penelitian ini dilakukan dengan metode eksperimen, menggunakan Rancangan Acak Kelompok (RAK). Itik yang digunakan sebanyak 100 ekor. Adaptasi itik selama 1 minggu, kemudian itik yang berjumlah 100 ekor dipilih sebanyak 80 ekor dan dikelompokkan menjadi 5 kelompok berdasarkan berat badan mulai dari yang terendah sampai tertinggi. Selanjutnya itik ditempatkan ke dalam kandang boks sebanyak 20 unit dengan tiap-tiap unit kandang berisi 4 ekor itik secara acak. Dalam satu kelompok diberikan 4 perlakuan tepung kunyit yang berbeda. Perlakuan tersebut terdiri atas:

Perlakuan 1 yaitu diberikan tepung kunyit dalam ransum percobaan itik sebanyak (0\%) per ransum, yang disebut A sebagai kontrol.

Perlakuan 2 yaitu diberikan tepung kunyit dalam ransum percobaan itik sebanyak
$(0,2 \%)$ per ransum, yang disebut sebagai B.

Perlakuan 3 yaitu diberikan tepung kunyit dalam ransum percobaan itik sebanyak $(0,4 \%)$ per ransum, yang disebut sebagai C.

Perlakuan 4 yaitu diberikan tepung kunyit dalam ransum percobaan itik sebanyak $(0,6 \%)$ per ransum, yang disebut sebagai D.

Apabila diantara perlakuan terdapat perbedaan, maka dilanjutkan dengan uji Duncan's Multiple Range Test/ DMRT (Steel dan Torrie, 1995).

\section{Pelaksanaan Penelitian}

Penelitian ini dilaksanakan dalam bentuk eksperimen dengan tahapan persiapan, adaptasi dan perlakuan. Pada tahap persiapan, kegiatan yang dilakukan adalah membuat tepung kunyit, mengatur dan membersihkan tempat pemeliharaan yang digunakan sedemikian rupa agar ternak merasa nyaman, menyiapkan peralatan kandang dan pengadaan bahan pakan penelitian.

1. Pembuatan tepung kunyit (Curcuma domestica val)

Tepung kunyit dibuat dengan cara rimpang kunyit dicuci terlebih dahulu, dikikis kulit luarnya yg masih tertinggal akar dan tanah, kemudian diiris tipis - tipis. Irisan kunyit tersebut kemudian diangin - anginkan selama 2 hari dan dioven dengan suhu $\pm 50^{\circ} \mathrm{C}$ selama 1 hari. Kunyit kemudian dihaluskan dengan blender dan disaring menggunakan ayakan menjadi tepung kunyit.

2. Persiapan Kandang

Dua minggu sebelum DOD masuk, kandang dibersihkan terlebih dahulu menggunakan air dan detergen, selanjutnya dilakukan penyemprotan kandang menggunakan formades yang telah diencerkan dengan air, kemudian dilakukan pengapuran. Satu hari sebelum DOD masuk, kandang dibersihkan kembali, dilakukan pemasangan lampu pijar untuk masing-masing kandang boks dan ditutup dengan tirai plastik.

3. Persiapan ransum penelitian 


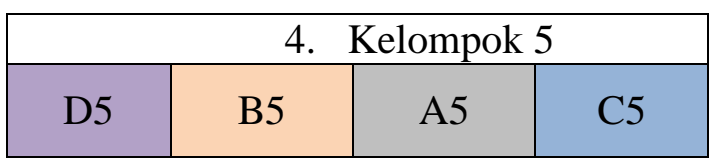

\begin{tabular}{|l|l|r|r|}
\hline \multicolumn{4}{|c|}{ Kelompok 1 } \\
\hline C1 & A1 & B1 & D1 \\
\hline
\end{tabular}

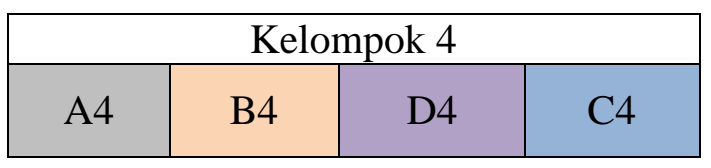

\begin{tabular}{|l|l|r|c|}
\hline \multicolumn{4}{|c|}{ Kelompok 2 } \\
\hline B2 & D2 & A2 & C2 \\
\hline
\end{tabular}

\begin{tabular}{|l|l|r|c|}
\hline \multicolumn{4}{|c|}{ Kelompok 3 } \\
\hline D3 & C3 & A3 & B3 \\
\hline
\end{tabular}

Gambar 1. Bagan penempatan itik pada kandang

Bahan-bahan penyusun ransum penelitian masing-masing ditimbang menurut komposisi ransum perlakuan, kemudian diaduk sampai merata. Pengadukan dimulai dengan bahan yang sedikit komposisinya dan dilanjutkan dengan bahan yang lebih banyak komposisinya sampai terlihat homogen.

5. Perlakuan dan penempatan itik dalam kandang

Penempatan perlakuan untuk masing masing unit dilakukan secara acak dalam kelompok, yaitu dengan cara menuliskan huruf dan angka pada kertas sesuai dengan jumlah perlakuan dan kelompoknya, yaitu: A1-A5, B1-B5, C1-C5, D1-D5. Angka yang tertera pada kertas ditempatkan pada kandang perlakuan.

Pada saat pengelompokkan itik, dilakukan penimbangan terlebih dahulu untuk menentukan berat awal sebelum masuk perlakuan. Pengelompokkan berdasarkan atas berat terendah sampai yang tertinggi, yaitu :
a. Kelompok 1: $88 \mathrm{~g}-106 \mathrm{~g}$
b. Kelompok 2: $108 \mathrm{~g}-127 \mathrm{~g}$
c. Kelompok $3: 129 \mathrm{~g}-141 \mathrm{~g}$
d. Kelompok $4: 142 \mathrm{~g}-161 \mathrm{~g}$
e. Kelompok $5: 170 \mathrm{~g}-210 \mathrm{~g}$

6. Pemeliharaan

Pemberian ransum dilakukan sesuai dengan kebutuhan itik/hari menurut Wakhid (2013), dapat dilihat pada Tabel 2.

Ransum diberikan 3 x sehari yaitu pagi (pukul 08.00-09.00 WIB), siang (pukul 13.00 WIB) dan sore (pukul 17.00-18.00 WIB). Ransum diberikan dalam bentuk remah (mash) secara ad libitum dan air minum juga diberikan secara ad libitum.

Tabel 2. Kebutuhan ransum itik umur 0-10 minggu

\begin{tabular}{cc}
\hline Umur (Minggu) & Ransum/ekor/hari $(\mathrm{g})$ \\
\hline DOD - & 15 \\
$1-2$ & 41 \\
$2-3$ & 67 \\
$3-4$ & 93 \\
$4-5$ & 108 \\
$5-6$ & 115 \\
$6-7$ & 115 \\
$7-8$ & 120 \\
$8-9$ & 130 \\
$9-10$ & 145 \\
\hline
\end{tabular}

Keterangan: Wakhid (2013)

7. Penyembelihan

Hal - hal yang dilakukan dalam mempersiapkan itik hidup menjadi karkas adalah sebagai berikut :

a. Pemuasaan. Sebelum dipotong itik dipuasakan selama 12 jam untuk mengurangi isi saluran pencernaannya.

b. Pemotongan. Itik dipotong tepat pada bagian leher dekat kepala, dengan memotong vena jugularis, arteri karotid, esophagus dan trakhea.

c. Pengeluaran darah. Setelah dipotong itik dibiarkan tergantung dengan posisi kepala menghadap ke bawah selama kurang lebih 1 menit agar sebagian darahnya keluar, kemudian ditimbang. 
d. Penyeduhan (scalding). Itik dicelupkan dalam air panas pada suhu sekitar $90^{\circ} \mathrm{C}$ selama \pm 1 menit untuk memudahkan pencabutan bulu.

e. Eviserasi. Setelah dilakukan pencabutan bulu dengan manual menggunakan tangan, kemudian dilanjutkan dengan pengeluaran isi rongga perut yang dilakukan dengan membuat torehan mendatar pada daerah perut yaitu antara ujung tulang dada dengan pubis. Isi rongga perut ditarik keluar dengan tangan secara perlahan. Selanjutnya, pemotongan kepala, leher dan kaki. Karkas ditimbang secara utuh.

f. Pemisahan bagian paha dan dada, kemudian ditimbang.

\section{Peubah yang Diamati}

Karkas adalah bagian dari tubuh unggas tanpa darah, bulu, leher, kepala, kaki dan organ dalam kecuali paru - paru dan ginjal (Mulyono, 2004). Jadi, beberapa peubah yang diamati dalam penelitian ini adalah:

\section{a. Bobot karkas}

Bobot karkas adalah bobot bagian tubuh itik setelah dikurangi bulu, darah, organ dalam kecuali paru-paru dan ginjal, leher, kepala dan kaki (Moreng dan Avens, 1985). Bobot karkas dihitung dalam gram/ekor.

b. Persentase bagian - bagian karkas (persentase bagian paha dan dada)

Persentase bagian-bagian karkas diperoleh dengan cara membagi bobot bagian-bagian karkas (dada dan paha) dengan bobot karkas kemudian dikalikan $100 \%$ (Soeparno, 2005). Bobot bagian dada terdiri atas kulit yang berada di bagian dada dan daging yang melekat pada tulang sternum beserta tulang-tulangnya.

Sedangkan untuk bobot bagian paha terdiri atas kulit yang berada di bagian paha, daging yang melekat pada tulang pelvis ditambah daging dan tulang paha yang dipisahkan pada sendi antara femur dan tibia.

c. Persentase karkas

Persentase karkas adalah perbandingan antara bobot karkas dengan bobot hidup kemudian dikalikan dengan 100\% (Soeparno, 2005).

\section{HASIL DAN PEMBAHASAN}

\section{Pengaruh Perlakuan Terhadap Bobot Karkas}

Rataan bobot karkas itik dengan pemberian tepung kunyit (Curcuma domestica Val) selama penelitian dapat dilihat pada Tabel 3.

Tabel 3. Rataan bobot karkas itik per ekor selama penelitian

\begin{tabular}{cc}
\hline Perlakuan & $\begin{array}{c}\text { Bobot Karkas } \\
\text { (g/ekor) }\end{array}$ \\
\hline A (0,0\%Tepung Kunyit) & 881,80 \\
B (0,2\%Tepung Kunyit) & 869,80 \\
C (0,4\%Tepung Kunyit) & 857,00 \\
D (0,6\%Tepung Kunyit) & 863,60 \\
\hline SE & 25,49 \\
\hline
\end{tabular}

Keterangan: Berbeda tidak nyata $(\mathrm{P}>0,05)$

Hasil analisa keragaman memperlihatkan bahwa pemberian tepung kunyit (Curcuma domestica Val) dalam ransum itik menunjukkan pengaruh tidak nyata $(\mathrm{P}>0,05)$ terhadap bobot karkas. Hal ini disebabkan karena pemberian tepung kunyit dalam jumlah yang masih bisa ditolerir oleh itik, yaitu dari $0,2-0,6 \%$ di dalam ransum belum mampu untuk mempengaruhi bobot karkas secara signifikan, sehingga bobot karkas yang didapat hampir relatif sama dengan bobot karkas pada ransum kontrol. Di samping itu, pemberian tepung kunyit sampai dengan level $0,6 \%$ tidak mempengaruhi palatabilitas ternak itik. Meskipun Purwanti (2008) menyatakan bahwa kurkumin yang terkandung di dalam kunyit memiliki khasiat yang dapat mempengaruhi nafsu makan dengan mempercepat pengosongan isi lambung sehingga nafsu makan meningkat dan memperlancar pengeluaran empedu dalam meningkatkan aktivitas saluran pencernaan.

Diduga, bahwa tidak terlihatnya efek pemberian tepung kunyit di dalam ransum juga dikarenakan ransum pada semua perlakuan disusun berdasarkan isoprotein dan isoenergi, dengan menyamakan kebutuhan akan protein (ransum fase starter umur 0-4 
minggu sebanyak $20,26 \%$ dan ransum fase grower umur 5-10 minggu sebanyak 18,26\%) serta energi (pada fase starter $2902,1 \mathrm{Kkal} / \mathrm{Kg}$ dan fase grower $2806,1 \mathrm{Kkal} / \mathrm{Kg}$ ). Seperti yang dinyatakan Sudiyono dan Purwatri (2007) bahwa bobot karkas dipengaruhi oleh konsumsi ransum, kandungan energi dan protein, bobot karkas menjadi relatif sama.

Anggorodi (1995) juga menyatakan bahwa itik diberi ransum secara ad libitum, akan makan terutama untuk memenuhi kebutuhan energinya dan apabila itik diberi ransum dengan kandungan energi metabolis rendah, maka itik akan mengkonsumsi lebih banyak. Hal ini sesuai dengan pendapat Wahju (1997), bahwa jumlah ransum yang dikonsumsi akan menentukan bobot hidup yang diperoleh, semakin banyak ransum yang dikonsumsi semakin meningkat pula bobot hidup yang dihasilkan, begitu pula dengan bobot karkasnya.

Menurut Ricardo (2014), rataan bobot karkas itik Pitalah umur 8 minggu dengan sistem pemeliharaan ekstensif yaitu 464,14 g. Sedangkan dari hasil penelitian dengan menggunakan tepung kunyit sampai 0,6\% dalam ransum didapat rataan bobot karkas yang lebih tinggi yaitu 857-880,81 g pada saat umur panen 10 minggu. Hal ini dikarenakan oleh sistem pemeliharaan, umur dan pakan yang berbeda.

Hasil penelitian dengan menggunakan tepung kunyit sampai dengan $0,6 \%$ dalam ransum didapat rataan bobot karkas yang hampir sama dengan hasil penelitian Cakra, Siti, Wiyana dan Umiarti (2009) yaitu bobot karkas itik Bali umur 10 minggu berkisar antara 854-915,40 g dengan menggunakan polar dan additif Duck Mix sebagai pengganti sebagian ransum komersial. Namun hasil penelitian ini lebih rendah jika dibandingkan dengan penelitian Matitaputty (2002) yang mendapatkan rataan bobot karkas itik Mandalung umur 10 minggu sebesar 1101,2 g. Perbedaan terhadap bobot karkas yang dihasilkan, disebabkan oleh jenis itik dan pakan yang diberikan berbeda. Sesuai dengan pendapat Tambunan (2007), bahwa bobot karkas dipengaruhi oleh jenis itik, jumlah dan kualitas ransum disamping bobot hidup, perlemakan, jenis kelamin, umur dan aktivitas. Selain itu, laju pertumbuhan ternak, genetik dan bobot non karkas juga mempengaruhi terhadap bobot karkas yang dihasilkan (Soeparno, 2005).

\section{Pengaruh Perlakuan Terhadap Persentase Bagian-Bagian Karkas (Dada dan Paha)}

Rataan persentase bagian - bagian karkas itik dengan pemberian tepung kunyit (Curcuma domestica Val) selama penelitian dapat dilihat pada Tabel 4.

Tabel 4. Rataan persentase dada dan paha itik per ekor selama penelitian

\begin{tabular}{ccc}
\hline Perlakuan & $\begin{array}{c}\text { Persentase } \\
\text { Dada }(\%)\end{array}$ & $\begin{array}{c}\text { Persentase } \\
\text { Paha }(\%)\end{array}$ \\
\hline A (0,0\%Tepung & 27,20 & 24,50 \\
Kunyit) & & \\
B (0,2\%Tepung & 27,99 & 24,70 \\
$\begin{array}{c}\text { Kunyit) } \\
\text { C (0,4\%Tepung } \\
\text { Kunyit) }\end{array}$ & 26,98 & 24,13 \\
$\begin{array}{c}\text { D (0,6\% Tepung } \\
\text { Kunyit) }\end{array}$ & 26,95 & 24,01 \\
\hline SE & 0,71 & 0,49 \\
\hline
\end{tabular}

Keterangan: Berbeda tidak nyata $(\mathrm{P}>0,05)$

Hasil analisa keragaman memperlihatkan bahwa pemberian tepung kunyit (Curcuma domestica Val) dalam ransum itik menunjukkan pengaruh tidak nyata $(\mathrm{P}>0,05)$ terhadap persentase bagian dada dan paha. Hal ini disebabkan oleh pemberian tepung kunyit sampai dengan $0,6 \%$ masih bisa ditolerir oleh itik, sehingga belum bekerja optimal dalam memacu pencernaan dan pertumbuhan pada itik termasuk pertumbuhan bagian paha dan dada. Meskipun Bintang dan Nataamijaya (2006) melaporkan bahwa tepung kunyit mengandung kurkumin yang bersifat antibakteri dapat menghambat pertumbuhan bakteri terutama pada saluran pencernaan sehingga meningkatkan pertumbuhan, sementara minyak atsiri kunyit bersifat bakteriostatik terhadap E.coli.

Pemberian tepung kunyit sampai $0,6 \%$ berpengaruh tidak nyata terhadap persentase bagian paha dan dada $(\mathrm{P}>0,05)$ juga dikarenakan oleh pemberian tepung kunyit 
berpengaruh tidak nyata terhadap bobot karkas $(\mathrm{P}>0,05)$ yaitu bobot karkas yang didapat pada perlakuan A $(881,80 \mathrm{~g})$, perlakuan B $(869,80$ $\mathrm{g})$, perlakuan $\mathrm{C}(857 \mathrm{~g})$ dan perlakuan $\mathrm{D}$ $(863,60 \mathrm{~g})$ sebagai penentu besar kecilnya bagian dada dan paha relatif sama, sehingga persentase bagian dada dan paha juga relatif sama. Ini dikarenakan persentase bagian dada dan paha didapat dari hasil perbandingan antara bobot dada dan paha yang dibagi dengan bobot karkas, kemudian dikali 100\% (Soeparno, 2005).

Menurut Lestari (2011), persentase bagian dada pada itik Alabio jantan umur 10 minggu sebesar $31,88 \%$. Sedangkan pada hasil penelitian dengan menggunakan tepung kunyit sampai $0,6 \%$ dalam ransum didapat persentase bagian dada yang lebih rendah berkisar antara 26,95-27,99\%. Akan tetapi, hasil penelitian ini tidak jauh berbeda dengan penelitian yang dilakukan Sudiyono dan Purwatri (2007) yang menggunakan enzim dalam ransum itik lokal jantan umur 10 minggu, didapat persentase bagian dada sebesar 26,96-29,02\%. Jika dibandingkan dengan penelitian yang dilakukan Amaludin et al., (2013), persentase bagian dada yang didapat pada itik Mojosari afkir berkisar antara 21,87-23,78\% maka penelitian dengan menggunakan tepung kunyit sampai $0,6 \%$ dalam ransum lebih tinggi.

Pada bagian paha, menurut Sudiyono dan Purwatri (2007) didapat persentase paha pada itik lokal jantan umur 10 minggu dengan penambahan enzim dalam ransum berkisar antara 24,72-26,14\%, tidak jauh berbeda dengan hasil penelitian ini yang menggunakan tepung kunyit sampai $0,6 \%$ dalam ransum didapat rataan persentase bagian paha berkisar antara $24,01-24,70 \%$ pada saat umur panen itik 10 minggu. Akan tetapi, hasil penelitian ini lebih rendah dari penelitian yang dilakukan oleh Amaludin et al., (2013) terhadap itik Mojosari afkir yang mendapat persentase bagian paha sebesar 34,65-35,13\%. Perbedaan terhadap hasil penelitian ini diduga oleh jenis itik dan jenis pakan yang digunakan.

Merkley et al., (1980) menyatakan bahwa pakan merupakan salah satu faktor yang mempengaruhi persentase potongan karkas pada unggas terdiri atas bagian dada, punggung, paha dan sayap. Keberadaan pakan sangat penting bagi itik karena mengandung zat-zat nutrisi yang dibutuhkan untuk pembentukan komponen karkas dan komponen tubuh yang lain (Rasyaf,1989). Bagian paha merupakan bagian yang pertumbuhannya lebih awal daripada bagian lainnya (Swatland, 1984). Menurut Natasasmita (1990), paha pada itik menunjukkan kecepatan perkembangan yang sama dengan tubuh secara keseluruhan, dengan kata lain paha mempunyai pola pertumbuhan isogonik atau pertumbuhan yang seimbang dengan perkembangan tubuhnya sedangkan dada memiliki pertumbuhan heterogenik yang secara alamiah disebabkan oleh faktor genetik.

\section{Pengaruh Perlakuan Terhadap Persentase Karkas}

Rataan persentase karkas itik dengan pemberian tepung kunyit (Curcuma domestica Val) selama penelitian dapat dilihat pada Tabel 5.

Tabel 5. Rataan persentase karkas itik per ekor selama penelitian

\begin{tabular}{cc}
\hline Perlakuan & $\begin{array}{c}\text { Persentase } \\
\text { Karkas }(\%)\end{array}$ \\
\hline A (0,0\%Tepung Kunyit) & 63,35 \\
B (0,2\%Tepung Kunyit) & 63,06 \\
C (0,4\%Tepung Kunyit) & 63,47 \\
D (0,6\%Tepung Kunyit) & 63,35 \\
\hline SE & 0,38 \\
\hline
\end{tabular}

Keterangan: Berbeda tidak nyata $(\mathrm{P}>0,05)$

Hasil analisa keragaman memperlihatkan bahwa pemberian tepung kunyit (Curcuma domestica Val) dalam ransum itik menunjukkan pengaruh tidak nyata $(\mathrm{P}>0,05)$ terhadap persentase karkas. Hal ini disebabkan oleh pemberian tepung kunyit dalam jumlah yang masih bisa ditolerir oleh itik yaitu berkisar antara 0,2-0,6\% di dalam ransum, sehingga belum optimal untuk mempengaruhi bobot karkas dan bobot hidup sebagai faktor penentu dari besarnya persentase karkas yang akan dihasilkan. Meskipun Bintang dan Nataamijaya (2006) melaporkan bahwa tepung kunyit mengandung kurkumin yang bersifat antibakteri dapat menghambat pertumbuhan 
bakteri terutama pada saluran pencernaan sehingga meningkatkan pertumbuhan, sementara minyak atsiri kunyit bersifat bakteriostatik terhadap E.coli. Chattopadhyay et al., (2004) juga menyebutkan bahwa kurkumin dapat meningkatkan level sekresi plasma dan bikarbonat pankreas, serta meningkatkan aktivitas lipase, amilase dan tripsin yang disekresikan pankreas. Ditambahkan Yasni et al., (1983) bahwa kurkumin dan minyak atsiri di dalam kunyit mampu mempengaruhi kerja saraf dan kelenjar hipofisis yang berperan dalam mensekresikan hormon pertumbuhan.

Menurut Brake dan Havenstain (1993), persentase karkas berhubungan dengan jenis kelamin, umur dan bobot hidup. Karkas meningkat seiring dengan meningkatnya umur dan bobot hidup. Cakra (1986) menyatakan bahwa semakin tinggi bobot potong dan bobot karkas maka akan berpengaruh terhadap persentase karkas yang semakin tinggi. Soeparno (2005) menambahkan persentase karkas juga dipengaruhi oleh faktor kualitas ransum dan laju pertumbuhan. Sudiyono dan Purwatri (2007) menyatakan bahwa pertumbuhan yang baik tentunya akan menghasilkan berat badan yang tinggi serta mampu meningkatkan persentase karkas secara optimal.

Hasil penelitian dengan menggunakan tepung kunyit sampai $0,6 \%$ berbeda dengan penelitian yang didapat oleh Putri (2013) bahwa penambahan sari kunyit ke dalam pakan itik (20 $\mathrm{ml} / \mathrm{kg}$ pakan $)$ mampu meningkatkan persentase karkas dari 54,40\% (ransum kontrol) sampai $62,51 \%$ pada itik hibrida. Perbedaan terhadap hasil penelitian ini diduga oleh bentuk pengolahan dari kunyit yang diberikan dan jenis itik yang digunakan juga berbeda. Namun, hasil penelitian dengan penggunaan tepung kunyit sampai dengan $0,6 \%$ memiliki rataan persentase karkas yang lebih tinggi yaitu $63,06-63,47 \%$ daripada penggunaan sari kunyit tersebut.

Jika dibandingkan dengan hasil penelitian Cakra et al., (2009) yang menggunakan polar dan additif Duck Mix sebagai pengganti sebagian ransum komersil pada itik Bali, diperoleh rataan persentase karkas berkisar antara 57,72-58,73\% dan penelitian yang dilakukan Sudiyono dan Purwatri (2007) yang menggunakan penambahan enzim dalam ransum pada itik lokal jantan umur 10 minggu, didapatkan persentase karkas berkisar antara 52,93-54,78\%, maka hasil penelitian dengan menggunakan tepung kunyit sampai 0,6\% inipun juga lebih tinggi.

Udayana (2005) menyatakan bahwa persentase karkas yang rendah dipengaruhi oleh berat potong yang rendah pula, karena berat potong yang rendah bagian-bagian yang terbuang semakin banyak. Iskandar (2000) menjelaskan bahwa semakin bertambahnya umur itik dari umur 5 menjadi 10 minggu membawa peningkatan terhadap persentase bobot karkas dari 50-58\% menjadi 59-62\%.

\section{KESIMPULAN}

Berdasarkan hasil penelitian dapat disimpulkan bahwa pemberian tepung kunyit (Curcuma domestica Val) dalam ransum sampai dengan level $0,6 \%$ tidak mempengaruhi bobot karkas, persentase bagian-bagian karkas (dada dan paha) dan persentase karkas.

\section{DAFTAR PUSTAKA}

Akhadiarto, S. 2002. Kualitas fisik daging itik pada berbagai umur pemotongan. Pusat Pengkajian dan Penerapan Teknologi Budidaya Pertanian. BPPT.

Amaludin, F., I. Soswoyo dan Roesdiyanto. 2013. Bobot dan persentase bagianbagian karkas itik Mojosari afkir berdasarkan sistem dan lokasi pemeliharaan. Jurnal Ilmiah Peternakan 1 (3): 924-932.

Anggorodi. 1995. Nutrisi Aneka Ternak Unggas. Gramedia Pustaka Utama. Jakarta.

Bintang, I.A.K dan A.G.Nataamijaya. 2006. Karkas dan lemak subkutan broiler yang mendapat ransum dengan suplementasi tepung kunyit (Curcuma domestica val) dan tepung lempuyang (Zingiber aromaticum val). Prosiding Seminar Nasional Teknologi Peternakan dan 
Veteriner, Bogor, 5 - 6 September 2006 Puslitbang Peternakan, Bogor: 623 628.

Brake, J.G.B and S.E. Havenstain. 1993. Relationship of sex, age and body weight to broiler carcass yield and offal production. Poultry Sci. 72: 1137-1145.

Cakra, I.G.L.O., N.I.W. Siti., K.A. Wiyana dan A.T. Umiarti. 2009. Penggantian sebagian ransum komersial dengan polar dan aditif Duck Mix terhadap komposisi fisik karkas itik. Jurnal Agripet 9(2): 2834.

Chattopadhyay, I., K. Biswas., U. Bandyopadhyay and R.K. Banerjee. 2004. Turmeric and curcumin: biological actions and medicinal applications. Current Sci. 87: 44-53.

Darwis, S.N., A.B.D. Modjo Indo dan S. Hasiyah. 1991. Tanaman obat familia zingiberaceae. Badan Penelitian dan Pengembangan Pertanian Industri. Bogor.

Istiana. 1997. Resistensi Salmonella spp isolat itik alabio terhadap beberapa antibiotik. Jurnal Ilmu Ternak dan Veteriner. 3(2) : 106-110. Pusat penelitian dan Pengembangan Peternakan. Badan penelitian dan Pengembangan Pertanian Departemen Pertanian. Jakarta.

Matitaputty, P.R. 2002. Upaya memperbaiki pertumbuhan dan efisiensi pakan mandalung melalui fortifikasi pakan dengan imbuhan pakan avilamisina. Tesis. Bogor: Program Pascasarjana, Institut Pertanian Bogor.

Merkley,J.W., B.T. Weinland., G.W. Malone and G.W. Chaloupka. 1980. Evaluation of five commercial broiler carcass. Eviscested yield and component parts. Poult. Sci. 59 : 1755-1760.

Mulyono, S. 2004. Memelihara Ayam Buras Berorientasi Agribisnis. Penebar Swadaya. Jakarta.
Natasasmita, A. 1990. Tumbuh kembang pada ternak. Buletin Penelitian Universitas Djuanda.Bogor. 1 (1):45-50.

Pietta, P. G. 2000. Flavonoids as antioxidants. Reviews. Jurnal Nat Prod 63 : 10351042.

Pratikno, H. 2010. Pengaruh ekstrak kunyit (Curcuma domestica val) terhadap bobot badan ayam broiler (Gallus $S p$ ). Buletin Anatomi dan Fisiologi 18(2), Oktober 2010.

Purwanti. 2008. Kajian efektifitas pemberian kunyit, bawang putih dan mineral Zink terhadap performa, kadar lemak, kolesterol dan status kesehatan broiler. Thesis: Pascasarjana. Institut Pertanian Bogor.

Putri, R. A. 2013. Pengaruh penambahan sari kunyit (Curcuma domestica Val) terhadap persentase karkas, persentase lemak abdominal dan kadar kolesterol daging itik hibrida. Fakultas Peternakan. Universitas Brawijaya. Malang.

Rahmat, A dan E. Kusnadi. 2009. Peranan kunyit dalam memperbaiki performan ayam broiler yang mengalami cekaman panas. Seminar Nasional Peternakan Berkelanjutan di Universitas Padjajaran, Bandung.

Rasyaf, M. 1989. Beternak Itik. Kanisius. Yogyakarta.

Ricardo, A. Y. 2014. Gambaran bobot hidup, karkas, persentase karkas dan lemak abdomen tiga jenis itik lokal di pembibitan itik "ER" Payobasung, Payakumbuh. Skripsi: Jurusan Teknologi Produksi Ternak. Fakultas Peternakan. Universitas Andalas. Padang.

Sinurat, A.P., A.R. Setioko, A. Lasmini, dan P. Setiadi. 1993. Pengaruh tingkat dedak padi terhadap performan itik peking. Ilmu dan Peternakan 6(1) : 21-26.

Sinurat, A.P., T. Purwadaria., I.A.K. Bintang., P.P. Ketaren., N. Bermawie., M. Raharjo dan M. Rizal. 2009. 
Pemanfaatan kunyit dan temulawak sebagai imbuhan pakan untuk ayam broiler. Jurnal Ilmu Ternak dan Veteriner. 14(2): 90-96.

Soeparno. 2005. Ilmu dan Teknologi Daging. Gajah Mada University Press. Yogyakarta.

Srigandono, B. 1997. Ilmu Unggas Air. Gajah Mada University Press. Yogyakarta.

Steel, R.G.D dan J.H. Torrie. 1995. Prinsip dan Prosedur Statistik, Suatu Pendekatan Biometrik.Terjemahan. Judul asli : Principles and Procedures of Statistics, a Biometrical Approach. Penerjemah : Bambang S. Gramedia, Jakarta.

Sudiyono, T.H dan Purwatri. 2007. Pengaruh penambahan enzim dalam ransum terhadap persentase karkas dan bagian bagian karkas itik lokal jantan. Jurnal Pengembangan Peternakan Tropis 32 (4) : 270-277.

Swatland, H. J. 1984. Structure and Development of Meat Animal. Prenticed Hall Inc. Englewood. Cliffs. New Jersey.

Tambunan, I. R. 2007. Pengaruh pemberian tepung kertas koran pada periode Grower terhadap persentase karkas, lemak abdominal, organ dalam dan saluran pencernaan ayam broiler. Skripsi Fakultas Peternakan IPB. Bogor.
Tangendjaja, B., R. Matondang dan J. Diment. 1986 .Perbandingan itik dan ayam petelur pada penggunaan dedak dalam ransum selama fase pertumbuhan. Ilmu dan Peternakan 2(4) : 137-139.

Udayana, I.D.G.A. 2005. Pengaruh penggunaan lemak sapi dalam ransum sebagai pengganti sebagian energi jagung terhadap berat badan akhir dan persentase karkas itik Bali. Majalah Peternakan Universitas Udayana. Denpasar. 8 (2):41-44.

Wahju, J. 1997. Ilmu Nutrisi Unggas. Cetakan IV. Gadjah Mada University Press. Yogyakarta.

Wakhid, A. 2013. Beternak Itik. PT Agromedia Pustaka. Jakarta.

Wizna, Abbas H., Y. Rizal., A. Dharma dan PI. Kompiang. 2008. Improving the quality of sago pith and rumen content as poultry feed through fermentation by Bacillus amyloliquefaciens.Pakistan. J. Nut. 7(2) : $249-254$.

Yasni, S., K. Yoshile, and H. Oda. 1983. Dietary curcuma xanthorrhiza roxb. Increases Mitogenic Responses of Splenic Lymphocytes in Rats, and Alters Populations of The Lymphocytes in Mice. J. Nutr. Sci. Vitaminol., 39. p. 345-354. 